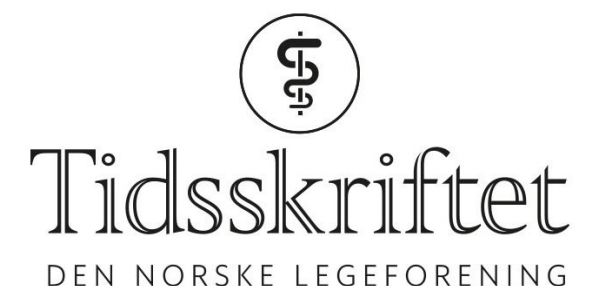

DEN NORSKE LEGEFORENING

\title{
Mink smitten, ikke smitt minken!
}

LEDER

\section{HANNAH JOAN JØRGENSEN}

E-post: hannah.jorgensen@vetinst.no

Hannah Joan Jørgensen er dr.med.vet. og veterinær med fagansvar for zoonoser ved

Veterinærinstituttet.

Forfatteren har fylt ut ICMJE-skjemaet og oppgir ingen interessekonflikter.

\section{OLE-HERMAN TRONERUD}

Ole-Herman Tronerud er veterinær og seksjonsleder i Mattilsynet. Forfatteren har fylt ut ICMJE-skjemaet og oppgir ingen interessekonflikter.

I Danmark ble flere millioner mink avlivet for å hindre spredning av et mutert koronavirus. Saken understreker koblingen mellom menneskers og dyrs helse.

Viruset SARS-CoV-2 gjorde et vertshopp fra dyr til menneske, ble tilpasset mennesker og i stand til å smitte mellom mennesker. I vår urbaniserte og globaliserte verden førte det til covid-19-pandemien. I november besluttet danske myndigheter å avlive 17 millioner mink av hensyn til folkehelsen.

I vår hersket det usikkerhet om SARS-CoV-2 kunne smitte husdyr og kjæledyr. Etter hvert ble det vist at kattedyr og ilder kan infiseres, mens andre testede dyrearter var lite mottakelige (1). Ilder og mink er beslektede arter. Derfor var det ikke overraskende da SARS-CoV-2 ble påvist hos mink i Nederland (2). Per i dag er det påvist smitte i over 6o minkfarmer i Nederland og over 280 i Danmark samt i noen flere land. I Norge er det ikke funnet smittet mink.

Det er mest sannsynlig mennesker som har brakt SARS-CoV-2 inn i minkfarmene. Når mange tusen mottakelige dyr står tett, er spredningsforholdene gunstige. I løpet av få uker har nær $100 \%$ av minken i berørte farmer blitt smittet (3). I store farmer kan viruset sirkulere over tid, smitte tilbake til røktere og spres i samfunnet (4). Den sterke økningen av smittede danske minkfarmer i høst var bekymringsfull. Når dyrehold utgjør et reservoar for zoonotiske smittestoffer, kan avliving av dyr i noen tilfeller berettiges.

Danskene fant flere mutasjoner i SARS-CoV-2-isolater fra mink. Én variant med mutasjoner i pigg (spike)-proteingenet (gruppe 5-viruset) lot seg ikke hemme av humant rekonvalesentserum i samme grad som andre SARS-CoV-2-virus. Statens Serum Institut mente at denne mutasjonen ville kunne unnslippe immunitet fra covid-19-vaksiner (5). Vurderingene var kontroversielle, og danskene er blitt kritisert for å ha lagt for stor vekt på dette (6). Det er naturlig at virus muterer, og sannsynligheten for mutasjoner øker med antall virusreplikasjoner. Når virus krysser artsbarrierer, kan mutasjoner bidra til en vertstilpasning, som kjent fra influensavirus (7). 
Det er antydet at gruppe 5-viruset er adaptert til mink (5). En vertstilpasning vil kunne gjøre viruset mindre farlig for den opprinnelige verten. Gjentatte passasjer av virus i celler fra en annen dyreart er en tradisjonell måte å lage attenuerte vaksinevirus (8). Gruppe-5-viruset, som ikke er påvist siden september (5), ser ikke ut til å være mer smittsomt eller farligere for mennesker enn andre SARS-CoV-2-varianter.

Å avlive covid-19-smittede mink kan forsvares, men det er vanskeligere å argumentere godt for å avlive en hel dyrepopulasjon i et land ut fra et føre var-prinsipp

Når skal friske dyr avlives av et føre var-hensyn til folkehelsen? Å avlive covid-19-smittede mink kan forsvares, men det er vanskeligere å argumentere godt for å avlive en hel dyrepopulasjon i et land ut fra et føre var-prinsipp, slik danskene besluttet. I Norge har vi en tradisjon innen dyrehelse for samarbeid mellom forvaltning, næring og kunnskapsinstitusjonene. Sykdomsutbrudd håndteres i fortløpende dialog der hensyn til dyrehelse og-velferd balanseres. Ved utbrudd av zoonoser samhandles det med helsemyndighetene.

Siden mennesker er den mest aktuelle smittekilden for SARS-CoV-2, er sannsynligheten for smitte av mink knyttet til smittesituasjonen i samfunnet. Veterinærmyndighetene har ansvar for å hindre smitteoverføring fra dyr til mennesker, og helsemyndighetene bistår med å hindre smitteoverføring fra mennesker til dyr. For å begrense smitte fra dyr til mennesker overvåker vi zoonoser hos norske husdyr. Påvisninger medfører restriksjoner på husdyrhold og sykdomsbekjempelse, iblant også avlivning av dyr. Kjøttkontroll og pasteurisering av melk er andre viktige tiltak som forebygger smitteoverføring mellom dyr og mennesker. Den gode norske dyrehelsen bevares også ved at importen av levende produksjonsdyr er minimal.

Smitteoverføring fra mennesker til dyr kan være krevende å forebygge. Norge var ett av få land der svinepopulasjonen var fri for influensavirus inntil den ble smittet med influensa A(H1 N1)pdmog av mennesker i 2009 (9). Mennesker har også smittet svin med meticillinresistente Staphylococcus aureus (MRSA) i Norge. Av folkehelsehensyn saneres MRSA-positive grisebesetninger i Norge ved utslakting av dyr samt vask og desinfeksjon av fjøs. Å kreve ekstra tiltak, som testing eller karantene for røktere, er etisk vanskelig, men iblant nødvendig. Vi gjør det ved MRSA, og nå tilbys minkrøktere regelmessig SARS-CoV-2testing.

Norsk pelsdyrhold skal avvikles innen 2025. Frem til det må vi minke smitten og hindre at mennesker smitter minken med covid-19. Vi som jobber med helsen enten hos mennesker eller hos dyr, må samhandle om felles smitteutfordringer. Åpenhet og kommunikasjon er vesentlig for å ivareta smittevern og for å hindre nye sykdommer i å etablere seg. Humanhelse, dyrehelse og miljøhelse henger sammen, og et samarbeid i et slikt én helseperspektiv gagner alle.

\section{LITTERATUR:}

1. Shi J, Wen Z, Zhong G et al. Susceptibility of ferrets, cats, dogs, and other domesticated animals to SARS-coronavirus 2. Science 2020;368: 1016-20. [PubMed][CrossRef]

2. Oreshkova N, Molenaar RJ, Vreman S et al. SARS-CoV-2 infection in farmed minks, the Netherlands, April and May 2020. Euro Surveill 2020; 25: 2001005. [PubMed][CrossRef]

3. Epidemiologisk udredning i SARS-CoV-2 smittede minkfarme. København: Dansk Veterinær Konsortium, 2020.

https://dkvet.dk/raadgivning/raadgivningssvar/covid-19-i-mink/Epidemiologisk_udredning_i_SARS-C OV-2_smittede_minkfarme_23-10-2020.pdf Lest 30.11.2020.

4. Notat om den seneste udvikling af SARS-CoV2 på minkfarme og blandt mennesker, 18. november 2020. København: Statens Serum Institut, 2020.

https://covid19.ssi.dk/-/media/cdn/files/notat-om-den-seneste-udvikling-af-sars-cov2-p-minkfarme-og-b 
landt-mennesker_181120.pdf?lada Lest 30.11.2020.

5. Risikovurdering af human sundhed ved fortsat minkavl, 3. november 2020. København: Statens Serum Institut, 2020.

https://files.ssi.dk/Risikovurdering-human-sundhed-ved-fortsat-minkavl-03112020 Lest 30.11.2020.

6. Kevany S, Carstensen T. Danish Covid mink variant 'very likely extinct', but controversial cull continues. The Guardian 19.11.2020.

https://www.theguardian.com/environment/2020/nov/19/danish-covid-mink-variant-very-likely-extinc t-but-controversial-cull-continues Lest 30.11.2020.

7. Schrauwen EJ, Fouchier RA. Host adaptation and transmission of influenza A viruses in mammals. Emerg Microbes Infect 2014; 3: e9. [PubMed][CrossRef]

8. Hanley KA. The double-edged sword: How evolution can make or break a live-attenuated virus vaccine. Evolution (N Y) 2011; 4: 635-43. [PubMed][CrossRef]

9. Hofshagen M, Gjerset B, Er C et al. Pandemic influenza $A\left(\mathrm{H}_{1} \mathrm{~N}_{1}\right) \mathrm{v}$ : human to pig transmission in Norway? Euro Surveill 2009; 14: 19406. [PubMed][CrossRef]

Publisert: 14. desember 2020. Tidsskr Nor Legeforen. DOI: 10.4045/tidsskr.20.096o

(C) Tidsskrift for Den norske legeforening 2020. Lastet ned fra tidsskriftet.no 